\title{
The Ecological Reserve: Towards a common understanding for river management in South Africa
}

\author{
E van Wyk ${ }^{1 *}$, CM Breen ${ }^{2}$, DJ Roux ${ }^{1}, \mathrm{KH}_{\text {Rogers }}{ }^{3}, \mathrm{~T}_{\text {Sherwill }}^{3}$ and BW van Wilgen ${ }^{4}$ \\ ${ }^{1}$ CSIR Natural Resources and the Environment, PO Box 395, Pretoria 0001, South Africa \\ ${ }^{2}$ Centre for Environment, Agriculture and Development, University of KwaZulu-Natal, Pietermaritzburg; Private Bag X01, \\ Scottville 3209, South Africa \\ ${ }^{3}$ Centre for Water in the Environment, University of the Witwatersrand, Private Bag 3, Wits 2050, South Africa \\ ${ }^{4}$ Centre for Invasion Biology, CSIR Natural Resources and the Environment, PO Box 320, Stellenbosch 7599, South Africa
}

\begin{abstract}
The legal requirement for an Ecological Reserve established in South Africa's water law is commonly regarded by stakeholders as being in direct competition with the needs of humans. This has resulted in much debate and varying interpretations of the meaning and purpose of the Ecological Reserve. However, the requirement for water that is allocated to sustain ecosystem functions is directly aligned with options for human use arising from rivers to deliver a suite of ecosystem goods and services to society. In this paper, we propose a conceptual approach to support a more constructive debate around the role and function of the Reserve in the sustainable use and protection of a suite of benefits to society. The approach proposes that debate be structured around managing for a dynamic ecological state in rivers that would in turn achieve the desired (albeit dynamic) mix of goods and services to a wide range of stakeholders. These stakeholders come from widely differing socioeconomic backgrounds, and their needs may be either for the direct use of water and associated resources located within the macro channels of rivers, or for their use in supporting social and economic activity remote from the river. The paper shows how goods and services concepts can provide an approach that contributes to developing a shared understanding that facilitates decisions on water allocations. The implication is that when water allocations can be evaluated comparatively it creates greater awareness of each other's needs and interdependencies and value is attached to a greater diversity of benefits and costs. This in turn allows for opportunities to achieve more equitable recognition and allocation of the resources associated with rivers. The approach assists in making the conceptual link between goods and services that arise from constructed production systems, and those that arise from natural production systems (i.e. ecosystems). Off-site as well as on-site use of river goods and services (the latter being catered for by the Ecological Reserve) can in this way be brought into debate in a way that promotes wider appreciation of society's diverse uses of river resources. In doing so it promotes interest-based participation as intended by legislation.
\end{abstract}

Keywords: Ecological Reserve, ecosystem services, water allocation, policy interpretation

\section{Introduction}

With a water law that is globally regarded as highly progressive and enabling (Postel and Richter, 2003), a vision of equity, efficiency and sustainability in the allocation and use of river resources (defined in this paper as river goods and services) seems within reach for South Africa. Prior to current legislation, water was the only formally recognised resource associated with rivers and water was allocated according to a rights-based system, to which only a few had access. In contrast, current policy defines rivers (entire river ecosystems) as the resource and promotes participative decision-making, where allocations should be driven by interest-based negotiations rather than rights (Dent, 2001). This is expected to lead to more equitable outcomes for resource sharing. But engaging in a negotiation-driven process requires a fundamental shift in mindset and practice based on mutual understanding of each other's resource-related needs and preferences and that these are dynamic over space and time (Van Wilgen et al., 2003; Breen et al., 2003).

Eight years have passed since the promulgation of the Water Act (Republic of South Africa, 1998). Its implementation, and

\footnotetext{
* To whom all correspondence should be addressed.

용 +2712841 3672; fax: +27 12841 2689;

e-mail: evwyk@csir.co.za

Received 26 May 2005; accepted in revised form 14 March 2006
}

in particular the development of a new decision-making process for resource allocation, has faced many obstacles. This is not surprising, since the objectives of legislation are ambitious and the changes required to achieve them are largely unprecedented. It has become clear that progressive new policy, new knowledge generated by science and wide commitment and energy for change, are not necessarily sufficient to achieve equity, efficiency and sustainability in the allocation and use of water resources.

Contributing to the challenge is the water law's premise that there is willingness to move away from rights-based bargaining to interest-based bargaining. Since the change requires those that previously held ownership rights to relinquish them and to share rights of use of the resource with others, it is assumed that people will voluntarily engage in negotiation for equitable sharing. But the historical situation has left a legacy of disparity in understandings and unfamiliarity with negotiations between those who have and those who do not, the strong and the weak, the informed and the uninformed, the heard and the unheard. Without the development of an interest-based, consensus-seeking approach to negotiations for resource sharing, tensions and conflict will hinder attainment of the policy intent of the Water Act of 1998.

In this paper, we consider the difficulties experienced in achieving a shared appreciation of the intent of allocating water to sustain river ecosystems (the Ecological Reserve), and how 
this affects our ability to negotiate and achieve an equitable balance among diverse needs within an interest-based system of negotiation. The 'ecological reserve' concept (hereafter called the 'Reserve') and its perceived intentions have stimulated considerable debate. Much of the frustration that has emerged has been directed at the law's requirement for allocating water to aquatic ecosystems in a country where demands on water are high and where in many instances, rights of use of available water have been already allocated, confounding attempts to reallocate water for development among marginalised groups. Framing the Reserve debate simplistically around the allocation of water is inconsistent with the intent of the legislation because in terms of the law, water is only one of many resources associated with rivers. River ecosystems are considered to provide a complex and dynamic array of resources valued by society. We propose an approach to support a more constructive debate around the role and function of the Reserve in promoting the sustainable use and protection of the benefits derived from water resources.

\section{Diverse interpretations of the Ecological Reserve}

The Ecological Reserve is an allocation of water specified as a volume and quality underpinned by flow and duration requirements to sustain the specified river ecosystem. Because it is an allocation of water, emphasis in dialogue is readily shifted from the concept of the river as the resource, to water being the resource. Not surprisingly perhaps, despite the opportunities presented by progressive and enabling legislation, implementation has been fraught with diverse perceptions of the intent and meaning of the Reserve (Table 1). This illustrates that dia- logue around the Reserve and its objectives is not appropriately structured to promote a shared understanding of a mix of human needs and preferences for the use of river resources (Sherwill et al., 2003). The dominant belief is that the needs of people compete with the needs of river ecosystems and that the Reserve strengthens this dichotomy.

Water allocated for the Reserve is perceived by some to be water that could have been more beneficially allocated to other uses. We argue that because the Reserve (a volume of water) is associated with 'servicing ecosystems' some actors do not link the Reserve water allocation with tangible benefits for society. The result is that water allocated for the Reserve is undervalued by many who participate in the debate as they often do not make the conceptual link between human well-being, river ecosystem services and water (Jewitt, 2002). Even when this link is acknowledged, if people fail to appreciate each other's needs and choices of how to derive benefit from the goods and services associated with rivers the value of the Reserve to society will not be fully appreciated. A further complicating factor is disparate way in which river ecosystem functioning and the derivation of benefits from the river resource is measured, valued and spoken about, with varied scientific, social and economic indices being used to describe human benefit.

The historic emphasis on water as a river resource has resulted in much of society failing to acknowledge and value the varied goods and services provided by rivers and their roles in sustaining life, especially in rural communities. The water law implicitly acknowledges these diverse goods and services and their users and in doing so entrenches the democratic principles necessary to safeguard equity in access to these resources. The intention of the law is that society should use and protect

\begin{tabular}{|c|c|}
\hline \multicolumn{2}{|c|}{$\begin{array}{l}\text { TABLE } 1 \\
\text { Examples of statements by various stakeholders, reflecting a variety of diverse perceptions relating to the } \\
\text { Ecological Reserve (water to maintain aquatic ecosystems in a defined state). These statements were re- } \\
\text { corded during a series of meetings convened to address issues around river management. (Adapted from } \\
\text { Sherwill et al., 2003). }\end{array}$} \\
\hline Statement & Assumptions implied or reinforced \\
\hline "The Reserve is water for 'bugs'” & The ultimate purpose of the Reserve is to prot \\
\hline $\begin{array}{l}\text { "We can only use the water that is left over after we have allocated } \\
\text { some for the ecology." }\end{array}$ & $\begin{array}{l}\text { People must compete with ecological systems for water; people's needs are } \\
\text { secondary to the requirements of natural systems. }\end{array}$ \\
\hline "More water for the Reserve means less water in your stomach." & $\begin{array}{l}\text { People must compete with ecological systems for water; higher levels } \\
\text { of protection for the resource means less allocation to (and associated } \\
\text { benefits for) people. }\end{array}$ \\
\hline $\begin{array}{l}\text { "How can you tell people they can't have water because the fish need } \\
\text { it?" }\end{array}$ & $\begin{array}{l}\text { People must compete with ecological systems for water; basic human need } \\
\text { denied in favour of ecosystems. }\end{array}$ \\
\hline $\begin{array}{l}\text { "Ecologists keep telling us about how the river ecosystem is the } \\
\text { resource, and not just the water it provides. But what is a river except } \\
\text { water?" }\end{array}$ & $\begin{array}{l}\text { Water is the only acknowledged component of the ecosystem; water provi- } \\
\text { sion is the only benefit to be had from river systems. }\end{array}$ \\
\hline "The Reserve is just there to give consultants jobs" & $\begin{array}{l}\text { The Reserve concept and processes to maintain it are by-products of self- } \\
\text { serving participation by ecologists, engineers and consultants. By defini- } \\
\text { tion then, the purpose of the Reserve is not to serve the needs of society. }\end{array}$ \\
\hline $\begin{array}{l}\text { "All we really need is sustainability. Why don't we just maintain all } \\
\text { rivers at the lowest protection level then we can get maximal use out } \\
\text { of them while still ensuring a sustainable resource?" }\end{array}$ & $\begin{array}{l}\text { The lowest levels of protection for the ecosystem translate to the provision } \\
\text { of maximum benefits to people, i.e. protection and use are disjunctive and } \\
\text { mutually exclusive. }\end{array}$ \\
\hline $\begin{array}{l}\text { "If } 10 \% \text { of the money already spent on Reserve determinations had } \\
\text { been spent on supplying water to rural areas, we'd have done more } \\
\text { good." }\end{array}$ & $\begin{array}{l}\text { Reserve determinations are perceived to be technical processes that waste } \\
\text { resources in light of more urgent basic human needs; meeting short-term } \\
\text { goals is more important than securing long-term sustainability. }\end{array}$ \\
\hline $\begin{array}{l}\text { "How did ecologists in South Africa manage to negotiate so much } \\
\text { power for protecting nature in the new water policy?" }\end{array}$ & $\begin{array}{l}\text { Nature and people are perceived to be separate entities with no interde- } \\
\text { pendent needs. Resource protection seen to be for protection's sake and } \\
\text { with no intention to accommodate human needs. }\end{array}$ \\
\hline $\begin{array}{l}\text { "We need to rethink the Reserve. The Reserve is there to maintain the } \\
\text { resource, which provides goods and services to people". }\end{array}$ & $\begin{array}{l}\text { People depend on the resource. Resource protection enables and supports } \\
\text { the use of resource-based benefits by people. }\end{array}$ \\
\hline
\end{tabular}


an agreed-upon suite of goods and services derived from each river. The view of rivers as a source of water, compared to the view of rivers as a resource of diverse goods and services, have rather different implications for how society can achieve equity in resource-sharing. Achievement of equity in resource sharing is contingent upon stakeholders having a shared understanding and approach that relates the Reserve to human needs and wellbeing.

\section{Linking aquatic ecosystems and human well-being}

River ecosystem goods and services sustain human life by supporting basic human needs, societal well-being and economic growth and development. They include tangible products such as water, food, forage, building and craft material (e.g. timber, sand and reeds), natural pharmaceuticals and industrial products and their precursors. The harvest and trade of these goods represent an important and familiar part of the human economy (Alcamo et al., 2003; Daily et al., 2001; Daily, 1997). Ecosystem services include a range of processes that support human wellbeing, for example the maintenance of water quality through filtration, waste disposal, as well as those benefits relating to recreational and spiritual needs.

People derive benefit from access to and use of on-site river ecosystem goods and services. For example they may engage consumptive processes such as watering and grazing livestock and harvesting animal and vegetable products. They may also engage in non-consumptive activities including recreation and religious ceremonies. Others, some of whom may never access rivers directly, derive benefit from the off-site use of river resources. Principal among these are the benefits accruing to people who use water abstracted from the rivers to service domestic and industrial needs at remote locations. Some of these uses may be consumptive such as extracting water for irrigated agriculture, and others such as waste disposal may to a large extent be non-consumptive. Those who have direct association with rivers for enjoyment or survival hold greater awareness of the diversity and value of ecosystem goods and services than those whose survival is dependent on the use of these goods and services at locations remote from rivers, such as in urban environments. Both of these groups are linked to river ecosystems but their awareness of the linkages is different. We argue that this difference in awareness is a causal factor in the misunderstandings surrounding the intention of the Reserve.

\section{The Ecological Reserve: An ecological means to a socio-economic end}

South Africa's water policy is unashamedly anthropocentric in its promotion of a more equitable spread of benefits and costs associated with the use of water-reliant goods and services. 'The objective of managing the quantity, quality and reliability of the nation's water ...is to achieve optimum, long term, environmentally sustainable social and economic benefit for society from their use' (DWAF, 1997) and 'Ecological Reserve means the quantity and quality of water required...to protect aquatic ecosystems in order to secure ecologically sustainable development and use of the relevant water resource' (Republic of South Africa, 1998).

The emphasis placed on protection of aquatic ecosystems in the policy conveys the intention to promote the use and protection of a desired and acceptable set of benefits to society. The intention of allocating the Reserve is therefore to facilitate the management of rivers to continuously achieve desired states of goods and services deriving from rivers. In order to protect the full suite of water-derived benefits used by people, the legislation is aimed at making provision for the protection of goods and services that may be used both on- and off-site. As a result, in much the same way that a water licensing system was set up to ensure fair allocation of water outside of the river ecosystem, the Reserve was set up as a licensing system for allocation of water to secure river ecosystem goods and services so that an equitable balance could be struck between on- and off-site uses. Thus, the intention of the Ecological Reserve is to secure water to support the attainment of a (dynamic) ecological state that provides an equitably distributed package of desired goods and services (socio-economic state) to society - and not to protect ecosystems per se. The protection of river ecosystems is a means to achieve a socio-economic goal. Such a goal may typically include a mixture of extractive and non-extractive uses as well as on- and offsite uses of the river.

The conversation about what constitutes a desired mix of goods and services to society and the dynamic state of an ecosystem to support the desired mix, implies the need for ongoing trade-offs and negotiation (Heeg and Breen, 1994). The law makes provision for this through the water resource classification system, which provides for consistency in the description of classes, or desired states (i.e. 'natural', 'moderately used or impacted' or 'heavily used or impacted'). Each class represents a permissible but different balance between on-site and off-site use of the water resource (DWAF, 2004). The classification system is therefore a tool to assist resource users in reaching agreement on the suite of goods and services they would like the resource to deliver in a sustainable way. Progress towards the desired state of goods and services (class) would in turn be supported by the attainment of a dynamic state of the aquatic ecosystem. The state of the ecosystem should in turn be assessed and managed with reference to the hydrological, physico-chemical, biological and geomorphological variables that define the Reserve.

Viewed from this perspective, the Ecological Reserve is a technical tool defined in ecological and scientific terms, intended to be used in an interactive manner to establish the connection between desired states of availability of river goods and services and the ecological state of the river (Fig. 1). In this way a scientifically defensible procedure is subject to and supportive of a wider process of collective interest-based bargaining and consensus around what people want the resource to deliver. It is this process that holds promise for building shared understanding if participants can be encouraged to appreciate each other's needs, preferences and values (Van Wilgen et al., 2003; Borsuk et al., 2001).

The water law recognises explicitly that the delivery of diverse goods and services will require the maintenance of a dynamic river ecosystem state. Thus the legislation required redefinition of the resource to include the entire aquatic ecosystem, not only water (Box 1). The importance of the way that the resource has been redefined lies in the recognition that the water in rivers provides benefits to people without ever leaving the water course. The Reserve allocation therefore gives effect to the definition of the Reserve (Box 1) through its role of managing the ecological interrelationships and functions that support the delivery of ecosystem goods and services. However, as dialogue around the Reserve tends to be highly technical and strongly focused on defining and meeting ecological objectives, the connections between the (dynamic) ecological state, the definition of associated ecosystem goods and services and socio-economic objectives, are weakly developed. Not surprisingly therefore the 


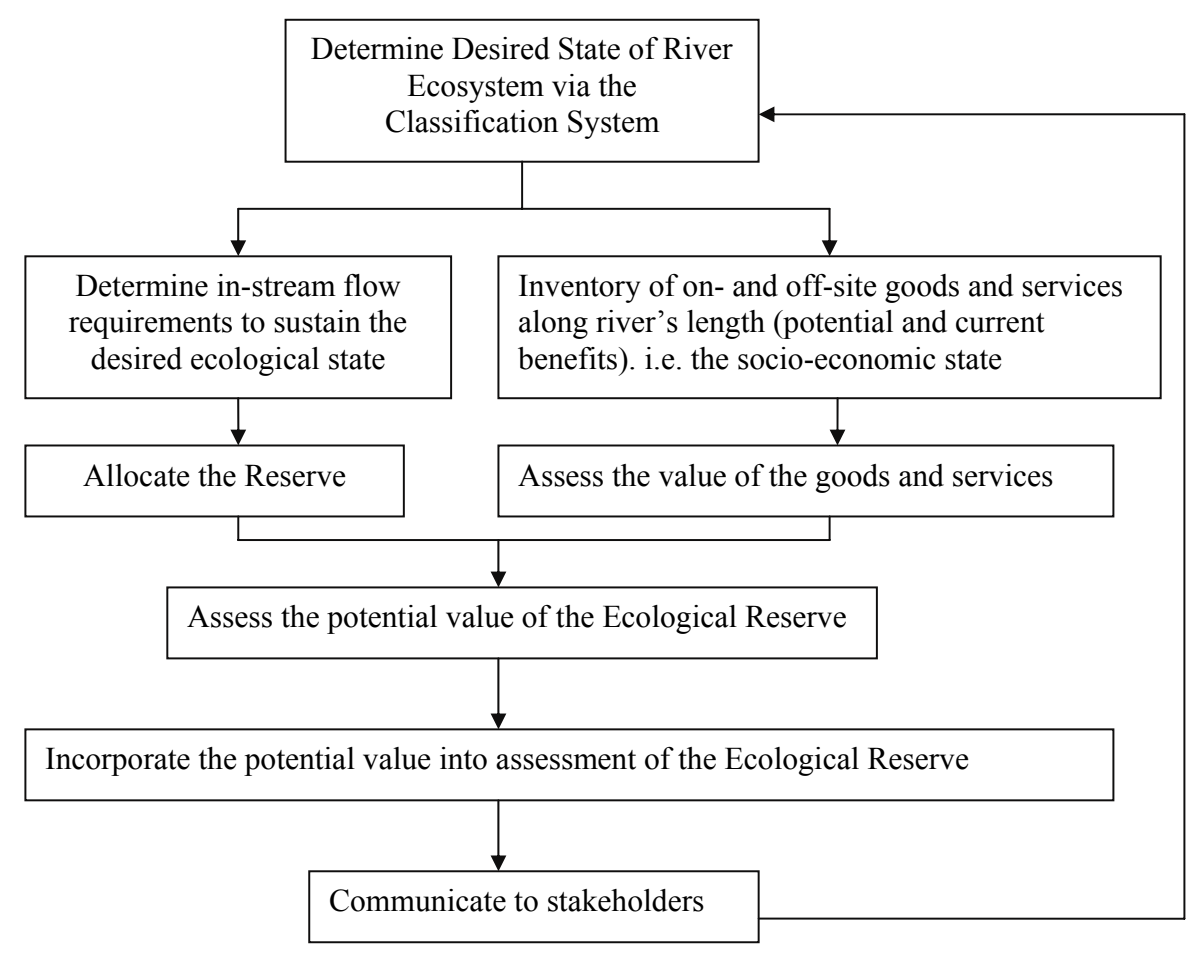

right (DWAF, 1997). This portion of water allocation sustains life and without it, people will not survive. Because this provides for an essential human need, the allocation of this water is guaranteed as a responsibility of the State and is therefore not negotiated. But what are the use-options for the rest of the water? Because the remaining 'allocatable' portion of water supports functions indirectly related to survival (i.e. reflects preferences for the ways in which our society and economy are grown and developed) and because of the growing scarcity of and demand for water to meet diverse needs, people have to negotiate among themselves how to allocate and use it (Fig. 2). The allocation of water to sustain the functioning of rivers so that they continue to provide goods and services along their length (the Reserve) lies at the heart of these negotiations. However, this realisa-

Figure 1

The purpose of the Reserve determination process and the subsequent Reserve water allocation is to support a desired suite of on- and off-site uses of the river along its length. This approach allows for the Reserve allocation to be valued in relation to other types of water allocations.

\section{Box 1: Definition of the water resource}

South Africa's water law acknowledges the entire ecosystem (and not only water) as a life support system. The 'resource' is defined to include a watercourse, surface water, estuary or aquifer, on the understanding that a watercourse includes rivers and springs, the channels in which water flows regularly or intermittently, wetlands, lakes and dams into or from which water flows, and where relevant the bed and banks of the system. The quality of the resource is also defined broadly to include fluxes in flow; physical, chemical and biological characteristics of the water; the character and condition of the in-stream and riparian habitat; and composition, condition and distribution of the aquatic biota. The resource was thus seen by drafters of the law in a holistic sense: the water the ecosystem of which it is a part and through which it flows and which influences the quality and quantity of water and the ecological processes that make up the resource. The Ecological Reserve was therefore set up to achieve a dynamic ecological state of the resource that provides a range of benefits to society through the provision of aquatic goods and services.

Reserve is often equated with sustaining ecosystems at the cost of benefit to society (Table 1).

\section{Towards a common understanding of water al- location}

Legislation views access to water for basic human needs (including water for drinking, cooking and sanitation) as a tion is not widely appreciated because there is as yet, in South Africa at least, no common understanding of the Reserve being an ecological means to achieving socio-economic ends. In addition the differentiation of stakeholders into those who use the goods and services on-site and off-site and those benefiting at different locations along the river, presents a challenge for understanding and appreciating each other's needs and aspirations. This is particularly so where there are differences in culture, disparities in economic development and where subsistence needs are undervalued when compared with priorities for economic growth. In essence, the allocation of water for the Reserve has as much to do with achieving an ecological state as with achieving an equitable social state. Figure 2 thus illustrates two points. First, it indicates that water allocated to river ecosystems and water allocated for use outside of the river ecosystem serve the same objective, although via a different route. Secondly, it shows that the Reserve secures a set of river-based benefits to people which were not recognised by previous legislation; and, in doing so, the National Water Act (1998) strives to promote a more equitable spread of benefits (as well as costs) to all who use the resource. It would seem that until this intention is more widely understood and appreciated, dialogue around the allocation of water to sustain river ecosystems will be challenging.

One approach to promote shared understanding is to demonstrate that whether water is left in the ecosystem (i.e. the Reserve) or it is abstracted for use outside of the river system, it serves the same purpose, namely to meet society's needs. The difference is that for some people, these needs are met through the on-site use of river goods and services and for other people, they are met through the off-site use of river goods and services. In both instances needs are met through the production of goods and the supply of services. In this sense river ecosystems are 'production systems' in much the same way as industry is a producer of goods and services for society. When both types of allocations are seen to serve the same purpose, it becomes possible to resolve the incompatible perceptions illustrated in Table 1. 


\begin{tabular}{|c|c|c|c|c|c|}
\hline Water allocation & \multicolumn{3}{|l|}{ Purpose of water } & End objective & Mode of allocation \\
\hline $\begin{array}{l}\text { Water for basic } \\
\text { human need }\end{array}$ & \multicolumn{3}{|c|}{$\begin{array}{l}\text { To support basic human needs, e.g. drinking water, cooking and } \\
\text { sanitation. }\end{array}$} & $\begin{array}{l}\text { Meet human } \\
\text { survival } \\
\text { needs }\end{array}$ & $\begin{array}{l}\text { A basic right, non- } \\
\text { negotiable }\end{array}$ \\
\hline $\begin{array}{l}\text { The Ecological } \\
\text { Reserve allocated } \\
\text { to sustain the } \\
\text { aquatic ecosystem }\end{array}$ & $\begin{array}{l}\text { To sustain a dynamic } \\
\text { desired state of the } \\
\text { ecosystem }\end{array}$ & $\begin{array}{l}\text { State of the } \\
\text { ecosystem is } \\
\text { associated with a } \\
\text { specific range of } \\
\text { goods and services } \\
\text { e.g. subsistence } \\
\text { fishing and } \\
\text { recreation }\end{array}$ & $\begin{array}{l}\text { Use of goods and } \\
\text { services support a } \\
\text { range of costs and } \\
\text { benefits }\end{array}$ & $\begin{array}{l}\text { DESIRED } \\
\text { SOCIAL } \\
\text { WELL-BEING } \\
\text { AND } \\
\text { ECONOMIC }\end{array}$ & $\begin{array}{l}\text { Resource class is } \\
\text { negotiated through } \\
\text { ongoing stakeholder } \\
\text { dialogue and } \\
\text { consensus based on } \\
\text { trade-offs between } \\
\text { diverse needs and } \\
\text { preferences } \\
\text { (Van Wilgen et al, 2003) }\end{array}$ \\
\hline $\begin{array}{l}\text { Water abstracted } \\
\text { from the } \\
\text { ecosystem (i.e. for } \\
\text { licensed use) }\end{array}$ & \multicolumn{2}{|c|}{$\begin{array}{l}\text { To support activities that rely on water } \\
\text { applied remote from the ecosystem, e.g. } \\
\text { irrigation }\end{array}$} & $\begin{array}{l}\text { Production of goods } \\
\text { and services to } \\
\text { support a range } \\
\text { of costs and } \\
\text { benefits }\end{array}$ & & \\
\hline
\end{tabular}

Figure 2

Different types of water allocation, and associated objectives as intended by South African legislation. Water allocated to river ecosystems and water allocated for use outside of the river ecosystem serve the same objective, although via a different route.

It emerges that stakeholders do not presently use a common approach within which to conduct negotiations around the allocation of water. We suggest that perceiving the Reserve (an allocation of water) to be the means to sustain a producer (the linear river ecosystem) of goods and services that meet social objectives, provides an interpretation that is congruent with an approach based on the notion of production systems that use allocations of water from rivers. Using this approach of water allocations for the production of goods and services that meet social and economic ends would facilitate shared dialogue and interest-based bargaining (Table 2).

Stakeholders perceive the state of the resource in the context of the social and economic trade-offs they make based on the use of alternative ecosystem goods and services. This perception is strongly influenced by their location in relation to the resource. Users perceive the resource at their sites of use and are commonly much less aware of how others perceive and use the river resources distant from them. Everyone, regardless of background or training, can relate to the delivery of benefits to people and can therefore use ecosystem goods and services terminology to connect their own welfare to ecosystems and also relate their own welfare to the welfare of others. A commonly understood and used 'language' based on goods and services will facilitate improved understanding for all involved in the debate and will thus support interest-based discussion. With requirements for devolved resource management and meaningful participation and decision-making by the wider public in matters relating to natural resources (Robertson and Hull, 2001; Lubchenco, 1998), specialists also will need to close the divide between 'experts' and 'non-experts' by nurturing their relationships with interested groups and individuals (Ludwig, 2001; Mills and Clark, 2001). When such resource specialists work with stakeholders on behalf of resource management agencies, their inputs and contribution will only be trusted if their intentions are genuine and they speak with a common voice based on shared understanding (Chapman, 2000).

\section{A need to manage perceptions}

We have shown that the connections between water allocated to sustain ecological functioning, the variety of goods and services available from rivers and the diversity of users are not clearly understood or appreciated. Differing perceptions appear to be a source of conflict. Because of individual needs and prefer-

\section{Two contrasting perceptions of the Ecological Reserve and the implications of these for the nature of water} allocation

\begin{tabular}{|l|l|l|}
\hline Perception of the Reserve & $\begin{array}{l}\text { Implication of the perception in relation to the objectives of the } \\
\text { Reserve }\end{array}$ & $\begin{array}{l}\text { Mechanism to access re- } \\
\text { source allocation }\end{array}$ \\
\hline $\begin{array}{l}\text { The Reserve is water allocated } \\
\text { to sustain nature, not for } \\
\text { people. }\end{array}$ & $\begin{array}{l}\text { Objectives for society and ecosystems are seen as opposing and competing. } \\
\text { There is no incentive to recognise direct- and remote-use interdependencies } \\
\text { and thus to share understanding of needs. }\end{array}$ & $\begin{array}{l}\text { Motivation for and defense of a } \\
\text { right to allocation - rights-based } \\
\text { negotiation. }\end{array}$ \\
\hline $\begin{array}{l}\text { The Reserve is water allocated } \\
\text { to maintain an ecosystem } \\
\text { state that supports a mutually } \\
\text { agreed range of benefits to } \\
\text { society. }\end{array}$ & $\begin{array}{l}\text { Reserve allocation is seen to serve diverse societal objectives through an } \\
\text { ecosystem state. Objectives for the ecosystem and for people are not in } \\
\text { competition, but the balance between the range of human benefits (on-site } \\
\text { as well as off-site use) and the ecosystem state that supports such benefits } \\
\text { must be agreed upon and thus requires shared understanding of each others } \\
\text { interests, values and perceptions. From this, people will tend to seek com- } \\
\text { plementary interests in order to share the resource more effectively. }\end{array}$ & $\begin{array}{l}\text { Interest-based negotiation based } \\
\text { on the appreciation of and the } \\
\text { interests. Greater opportunity for } \\
\text { equitable outcomes compared to } \\
\text { rights-based negotiation. }\end{array}$ \\
\hline
\end{tabular}


ences, the way people perceive rivers differs, each allocating value to those goods and services that bring personal benefit and discounting intentionally or unintentionally, those that are not used or recognised by them. There are four dimensions to these perceptions that should be addressed explicitly if users are to reconcile their expectations in an equitable and sustainable manner. There must be:

- A wider shared understanding of the dynamic and diverse nature of the goods and services available from rivers along their whole length

- An appreciation of the value attached to these resources by those who use them and that not all desired uses may be accommodated

- An appreciation that deriving benefit may be associated with costs that are borne by others and that equity of access to use should be accompanied by equity in distribution of costs and benefits

- The availability of goods and services is determined by the condition of the river and the water allocated to sustain its functioning.

\section{Developing a wider shared understanding of diverse river goods and services}

Many river resource uses and associated activities are spatially separated and people are often unaware of the nature and scales (spatial, magnitude and time) of activities and impacts resulting from other's use of the resource. For example, people can catch fish directly from the river, or transport water to a fishery and produce and harvest fish there. The product is similar, but the costs, benefits and impacts of the two activities may be very different and they are likely to affect different people in different ways.

The challenges presented by past inequities in access to the resource and current efforts to redress inequities and inefficiencies have meant that much attention is now given to water and its allocation, quantifying the Reserve and establishing licensing procedures. Thus, the urgent need to ensure water provision for basic human needs and the focus on reallocating water more equitably for out of stream water use, has reinforced the substantial attention being given to water that is removed for off-site use. The downside of this is that the objective of the Reserve allocation and the associated diverse on-site river services to society become progressively diminished in people's minds. However, when viewed in the light of the approach suggested here, the value of the Reserve as an allocation that supports the provision of ecosystem-based (i.e. on-site) benefits to society is no less critical than the provision of benefits derived from other types of water allocations.

\section{Appreciating the value of goods and services}

Production systems that rely on abstracted water commonly give rise to products and benefits traded in an economic market place. In contrast, ecosystem goods and services typically do not carry 'price tags' that will alert society to changes in their supply or the deterioration of the ecological functions that generate those (Daily et al., 2001). Rivers, unlike man-made production systems (e.g. irrigation and industrial systems) are linear and distribute diverse goods and services to diverse people along considerable distances at no perceived cost.

Thus, river-based ecosystem goods and services and their underlying production systems tend to be undervalued. Under previous legislation, activities such as subsistence fishing and recreation, the maintenance of water quality and healthy estuaries, were not formally acknowledged as adding value to human well-being. Because of this, people may not perceive ecosystems to be life-supporting 'production systems' and hence may not value ecosystem-based goods and services. As a result it may be difficult for the users of the two different production systems (i.e. on-site and off-site) to appreciate each other's resource-related costs and benefits.

Goods and services based on freshwater ecosystems are easily taken for granted, because they become available with minimal or no investment. Also, most 'in-stream' benefits have strong 'public good' characteristics that make it difficult to capture their full value in an economic marketplace. For example, it can be difficult or impossible to exclude anyone from enjoying the benefits of public good resources, whether they pay for the benefit or not. In such cases where the benefits and beneficiaries are not easily identifiable, the value of river services is difficult to estimate. The value of these types of ecosystem services often becomes evident only once they are lost (Daily, 1997).

\section{Understanding the relationships between river condi- tion and availability of goods and services}

People may not have appreciated, in the past or even now, that ecosystems are dynamic in their nature and as a result, deliver goods and services in an inconsistent manner. People generally prefer to benefit consistently. However, promoting and achieving consistency in the delivery of ecosystem services often means modification of the ecosystem to a different, less dynamic state (e.g. through the building of dams). While consistency in delivery of some goods and services may thus be achieved, reducing ecosystem variability affects the ability of the ecosystem to buffer change (Gunderson and Holling, 2002) and as a result, the nature and composition of the basket of goods and services that becomes available to a catchment community may be altered. Balancing the need for consistent as well as more dynamic delivery of goods and services should be made explicit through the negotiation process so that the mix of values is reflected in water allocation and use. It follows then that we need to foster an understanding of the linkages between the dynamic condition of river ecosystems and ability of these systems to sustain the ongoing provision of a variable supply of goods and services.

\section{Concluding remarks}

Past and perhaps current perceptions around the Reserve do not encourage a mutual understanding and appreciation of the diversity of values attached to goods and services derived from water resources. This has critical implications for achieving policy objectives, because if people are unable to make the shift from a rights-based system to a paradigm under which diverse interests are understood and reconciled, they will not achieve equity in the distribution of resource-related costs and benefits.

The emphasis on 'Ecological' and 'Reserve' in establishing the policy for an Ecological Reserve to sustain river systems understandably conveyed to the public a conservation and protection intent. The intent that the Ecological Reserve should secure river systems so that they would continue to provide goods and services for society was not explicit and was easily lost in emotive debate around conservation and protection that could be portrayed as a system for denying people access to goods and services. The evidence indicates that the connections between the Ecological Reserve and the availability of goods and services, the principal intent of the policy, must be strengthened. 
However, as the beneficiaries of river goods and services have diverse, changing and secular interests, and may be spatially and conceptually separated, developing shared understanding is difficult. Yet this shared understanding is essential for interestbased bargaining to function meaningfully. We agree that the scientific determination of an Ecological Reserve is important and that although its outcome is expressed in biological and ecological terms, it relates directly to river functioning, which in turn relates to ecosystem goods and services and the resulting distribution of resource-related costs and benefits in society.

\section{Acknowledgements}

We thank the Water Research Commission for funding (through WRC Project No 1062/1/03: Principles and processes for supporting stakeholder participation in integrated river management: lessons from the Sabie-Sand catchment) and Bill Rowlston, Henk van Vliet, Heather MacKay, Liesl Hill and Sakkie van der Westhuizen for their insights and support for the development of these ideas.

\section{References}

ALCAMO J et al.(2003) Ecosystems and Human Well-being. A Framework for Assessment. The Millenium Ecosystem Assessment. Island Press, Washington. 245 pp.

BORSUK M, CLEMEN R, MAGUIRE L and RECKHOW K (2001) Stakeholder values and scientific modelling in the Neuse River Watershed. Group Decisions and Negotiation 10 355-373.

BREEN CM, COX D, DICKENS C, MACKAY H, MANDER M, ROUX DJ, TURTON A and VAN WYK E (2003) Strategic Review of River Research. WRC Report No. 1198/1/03. Water Research Commission, Pretoria.

CHAPMAN M (2000) Trust and its Relevance to Individuals and Groups in Institutions Facing Change. University of Lincolnshire and Humberside. 392 pp.

DAILY GC (1997) Nature's Services - Societal Dependence on Natural Ecosystems. Island Press, Washington DC.

DAILY GC, ALEXANDER S, EHRLICH PR, GOULDER L, LUBCHENCO J, MATSON PA, MOONEY HA, POSTEL S, SCHNEIDER SH, TILMAN D and WOODWELL GM (2001) Ecosystem
Services: Benefits Supplied to Human Societies by Natural Ecosystems. Issues in Ecology. Ecological Society of America. http:/ www.esa.org/science/Issues/FileEnglish/issue2.pdf. Accessed on 11 January 2006.

DENT CM (2001) Installed water resource modelling systems for catchment management agencies. Water SA 27 (3) 333-340.

DEPARTMENT OF WATER AFFAIRS AND FORESTRY (DWAF) (2004) National Water Resource Strategy (1 ${ }^{\text {st }}$ edn.). Government Printer. Pretoria.

DEPARTMENT OF WATER AFFAIRS AND FORESTRY (DWAF) (1997) White Paper on a National Water Policy for South Africa. Pretoria, South Africa.

GUNDERSON LH and HOLLING CS (eds.) (2002) Panarchy: Understanding Transformations in Human and Natural Systems. Island Press, Washington. 507 pp.

HEEG J and BREEN CM (1994) Resolution of conflicting values on the Pongolo River and floodplain (South Africa). In: Patten BC (ed.) Wetlands and Shallow Continental Water Bodies 2 303-359. SPB Academic Publishing. The Hague.

JEWITT G (2002) Can integrated water resources management sustain the provision of ecosystem goods and services? Phys. Chem. Earth 27 887-985.

LUBCHENCO J (1998) Entering the century of the environment: A new social contract for science. Sci. 279 491-497.

LUDWIG D (2001) The era of management is over. Ecosyst. 4 758764.

MILLS TJ and CLARK RN (2001) Roles of research scientists in natural resource decision-making. For. Ecol. Manage. 153 189-198.

POSTEL S and RICHTER B (2003) Rivers for Life: Managing Water for People and Nature. Island Press, Washington, DC. 253 pp.

REPUBLIC OF SOUTH AFRICA (1998) National Water Act. Act No. 36 of 1998. Pretoria, South Africa.

ROBERTSON DP and HULL RB (2001) Beyond biology: toward a more public ecology for conservation. Conserv. Biol. 15 (4) 970-979.

SHERWILL T, ROGERS KH and VAN WYK E (2003). The Ecological Reserve: For People or for Insects and Fish? Water Wheel 2 (3) 9-11.

VAN WILGEN BW, BREEN CM, JAGANYI JJ, ROGERS KH, ROUX DJ, SHERWILL T, VAN WYK E and VENTER F (2003) Principles and Processes for Supporting Stakeholder Participation in Integrated River Management: Lessons from the Sabie-Sand Catchment. ISBN: 1-86845-966-7. WRC Report No. 1062/1/03. Water Research Commission, Pretoria. South Africa. 